\title{
Os limites do escrito: contratos e relações de trabalho com libertos em Vitória ao final do século XIX
}

\author{
The limits of the written word: contracts and labor \\ relations with former-slaves in Vitória (Brazil) \\ at the end of the XIX century
}

Geraldo Antonio Soares*

Resumo: Este trabalho trata de casos de escravos que conseguiram suas alforrias mediante empréstimos e contratos de locação de serviços. Notamos a expectativa de que os que conquistaram a liberdade continuassem a trabalhar como quando eram escravos, o que evidentemente não estava nos planos desses libertos. Concluímos que as experiências históricas examinadas nos permitem o acesso a todo um conjunto de representações sobre o trabalho e sobre o que seria a vida em liberdade.

Palavras-chave: Escravidão. Emancipação. Trabalho livre.

Abstract: This paper deals with the cases of slaves who attained their release from slavery by means of loans and contracts for letting their services. We perceived the expectation that the freed slaves would continue to work as hard as when they were captives, something, of course, far away from the freedman's plans. We conclude that the historical experiences examined allow us the access to a whole set of representations on labor and the meaning of life in liberty.

Keywords: Slavery. Emancipation. Free labor.

* Doutor em História pela École des Hautes Études en Sciences Sociales - EHESS - Paris; Professor do Departamento de História da Universidade Federal do Espírito Santo. 
Com A integração do negro na sociedade de classes, publicado em 1965, Florestan Fernandes se tornou uma referência obrigatória para o estudo dos problemas enfrentados pelo negro no Brasil a partir da abolição da escravatura, notadamente a discriminação racial e social. Em um artigo de 1966, ele nos apresenta de forma condensada as teses centrais de seu livro escrito um ano antes.

Neste artigo, nos diz que no período que vai da abolição ao fim da Primeira República o negro enfrentou, no caso em São Paulo, as piores vicissitudes que se poderiam imaginar. Nesse período, ele caracteriza como transformações sociais, de um lado a intensificação das tendências de concentração racial da renda, do prestígio social e do poder, e de outro

a propensão do negro para lidar com a liberdade de forma que envolvia extrema irracionalidade. Representando-se como 'dono de seu nariz', pôs em prática ajustamentos que colidiam com a natureza do trabalho livre, da relação contratual e com as bases competitivas da nova estrutura social. (Fernandes, 1966, p. 83).

Examinando ainda os impactos da imigração estrangeira e do que chama de expansão da ordem social competitiva na cidade de São Paulo, no período que vai aproximadamente de 1885 a 1930, conclui que:

[...] a escravidão não preparara o seu agente de trabalho senão para os papéis socioeconômicos do escravo e do liberto no seio da ordem social escravocrata. Quando esta entra em crise e se desintegra, com ela também desaparecem as únicas condições econômicas e socioculturais que protegiam e garantiam os ajustamentos socioeconômicos do 'negro' ao sistema de trabalho. De repente, e sem estar preparado para os papéis socioeconômicos do homem livre, o 'negro' viu-se numa cidade que se torna, rapidamente, a principal cidadela da revolução burguesa no Brasil. [...] Acresce que o próprio 'negro' tinha de aprender a agir socialmente como trabalhador livre e a lidar com o mundo da economia urbana, sem ter tempo para isso. As coisas caminharam depressa demais. De modo que o desajustamento do 'negro', que poderia ser um fenômeno transitório, converteu-se em desajustamento estrutural. (Fernandes, 1966, p. 79).

Diz também que o negro tinha uma propensão a lidar com a liberdade de forma que envolvia extrema irracionalidade, mas não explicita quem, no caso, definia qual era a forma racional ou não de se 
lidar com essa liberdade. Entendemos que ao ex-escravo é que cabia construir a sua própria concepção de liberdade e esta concepção não tinha como não estar marcada pela dura e recente experiência de vida como escravo.

Nunca é demais lembrar, como o faz Sidney Chalhoub, que "para os negros, o significado da liberdade foi forjado na experiência do cativeiro" (Chalhoub, 1990, p. 27). Por isso é que as visões da liberdade dos ex-escravos nem sempre se ajustavam com a natureza da relação contratual e de uma sociedade competitiva.

Pode até ser que o ex-escravo não tenha se adaptado de imediato às tais "bases competitivas da nova ordem social", mas sabia ele que tal ordem se inaugurava? Provavelmente nem mesmo os seus novos patrões ou antigos senhores sabiam dessa novidade. Para estes, o que era importante é que os ex-escravos continuassem trabalhando como antes. Mas como não podiam mais usar o açoite, procuravam valorizar o trabalho independentemente de seus resultados em termos de remuneração e realização pessoal.

Para as elites ex-proprietárias de escravos, só o trabalho podia civilizar. Mas para o ex-escravo, talvez o que realmente importasse naquele momento fosse justamente "ser dono de seu nariz".

Ao afirmar que a escravidão não preparara o seu agente de trabalho senão para os papéis socioeconômicos do escravo e do liberto no seio da ordem escravocrata, acaba-se por incorporar na análise o próprio discurso das elites escravistas da época. Este era um dos argumentos tanto de progressistas, que assim defendiam a imigração estrangeira, como de conservadores, que procuravam postergar ao máximo a abolição. Não é outra a conclusão a que chega George R. Andrews, quando observa que as elites rurais e urbanas da virada do século teriam reconhecido nos escritos de Florestan Fernandes o seu negro, tal o nível em que ele exagera o que considera como o grau de patologia e desorganização social dos negros. (Andrews, 1988, p. 510).

Os trabalhos de Florestan Fernandes tem como uma de suas preocupações encontrar explicações para as desigualdades sociais e raciais existentes no Brasil da época em que escrevia, desigualdades sociais que sempre procurou combater enquanto homem público. Partindo dessa realidade, procura encontrar as raízes históricas de tais desigualdades. $\mathrm{O}$ ponto de partida em história não tem como não ser o presente na medida em que o historiador é um homem que pertence ao mundo em que vive e não ao mundo que analisa. As questões mesmas que são colocadas ao historiador, o são pelo seu presente. 
André Burguière, em seu artigo sobre o surgimento dos Annales, faz importantes observações a este respeito. Para ele,

este vai e vem do passado ao presente, os fundadores dos Annales o aceitam como um princípio de conhecimento perfeitamente reversível. O historiador não tem porque se perguntar se é o presente que o ajuda a compreender o passado ou o passado que o ajuda a compreender o presente. A confrontação dos dois lhe possibilita se desprender do meio ideológico através do qual ele se liga ao mundo que o envolve, e produzir um certo saber: que pode esperar mais? (Burguière, 1979, p. 1356).

Arlette Farge nos propõe uma boa síntese do que poderíamos chamar de uma certa tentação de mergulhar no passado. De acordo com ela:

$\mathrm{Na}$ verdade, o historiador, nós o sabemos, vê 'ao inverso', ou seja, quando o filme acabou; então ele interpreta o início, o olhar inevitavelmente embaçado pelas lembranças do fim. Tentar uma outra perspectiva é indispensável, e isto tem qualquer coisa de fatigante; tenho muitas vezes sonhado trabalhar nos arquivos ignorando o que acontece em seguida, numa espécie de imediaticidade ingênua, numa relação com o texto que seria uma utópica relação com o presente, a fim de deixar meu espírito descobrir fatos insignificantes, esquecidos (mal conhecidos) pela historiografia e, portanto, atores de um real jamais descrito nos livros de história. Esta perspectiva falsamente ingênua (e sem dúvida forçada) multiplica os questionamentos e se desenvolve em sentido contrário às certezas. (Farge, 1992, p. 190).

Cabe ao historiador a tarefa de fazer as devidas mediações entre o presente e o passado. Se conseguir fazer bem estas mediações, conseguirá também diminuir os riscos de incorrer em dois tipos de erros que lhe são capitais, quais sejam, o anacronismo e o determinismo.

Para Florestan Fernandes,

no fundo a transformação de status, pressuposta na passagem da condição de cativo ou de liberto para a de cidadão, não encontrou suportes econômicos, sociais e políticos que lhe dessem realidade histórica. Foi uma operação semântica; ou como diria um dos líderes do pensamento liberal, 'uma ironia atroz'. Ela deu forma e consolidou, nas regiões em crescimento econômico intenso, a última espoliação sofrida pelo escravo, pelo ingênuo e pelo liberto, praticamente expurgados do sistema de trabalho sem quaisquer compensações econômicas ou garantias sociais [...]. (Fernandes, 1966, p. 89). 
Não podemos dizer que neste artigo o autor incorra em anacronismos ou determinismos, o que seria injusto e mesmo leviano. Além do mais, estamos tratando apenas de um breve artigo e não do conjunto de sua obra, que possui méritos inegáveis, entre os quais, como assinala Sidney Chalhoub, ter demonstrado e denunciado, já nos anos 1960, juntamente com os trabalhos da historiadora Emília Viotti da Costa, a violência da escravidão brasileira, dando uma contribuição decisiva no que se refere à questão historiográfica do paternalismo versus violência na relação entre senhores e escravos no Brasil, embora estejamos de acordo com Hebe Maria Mattos, quando ela diz que não devemos nos esquecer de que "não há escravidão 'suave' ou 'cruel', ela dispensa adjetivos" (Mattos, 1998, p. 143). De qualquer modo, em passagens como a citada acima, ficamos sem saber se a análise é excessivamente materialista ou excessivamente pessimista. Nelas quase se chega a dizer que os escravos foram punidos com a abolição nas condições em que ela se deu.

Sem dúvida que na sociedade brasileira dos anos 1960 existiam - e ainda hoje existem - racismo e discriminação social contra os negros. Mas nosso presente de discriminação não se explica inteiramente por nosso passado escravista. Mais perigoso ainda seria localizar naquela época a origem de um desajustamento estrutural do negro na sociedade. Se assim o fizermos, acabamos por concluir que o nosso presente é como é, porque, pelo nosso passado, ele não poderia ser diferente, o que não é definitivamente uma boa maneira de se fazer história.

Passemos a personagens e a fatos concretos para tentar perceber, com dois exemplos, como alguns ex-escravos ao menos viam a sua nova relação de trabalho.

No dia 7 de agosto de 1879, o liberto Narciso de Souza, 26 anos, solteiro, jornaleiro, brasileiro, nascido na Vila do Espírito Santo (hoje Vila Velha), província do Espírito Santo, não sabendo ler e escrever, apresentou em juízo uma petição de habeas-corpus preventiva para evitar uma terceira prisão da qual se sentia ameaçado, prisão esta que seria a seu ver arbitrária, ilegal e violenta. Passa então a expor os motivos pelo quais se sentia ameaçado desta nova prisão.

Diz-nos Narciso que pedira emprestado a Antônio Alves de Azevedo, com 48 anos pouco mais ou menos, brasileiro, casado, empregado público, residente em Vitória, a quantia de trezentos e cinquenta mil réis $(350 \$ 000)$ para completar o preço de sua liberdade, hipotecando, na forma exigida pelo mesmo Azevedo, seus serviços por sete anos, por um contrato particular e extrajudicial. Continua sua exposição de 
motivos na petição dirigida ao juiz, dizendo que tendo já trabalhado juntamente com sua mãe por mais de oito meses para seu locatário, este apenas lhe descontou a quantia de $50 \$ 000$, ou $5 \$ 000$ mensais, em vista disto, propôs ao seu locatário prestar-lhe serviços por preço razoável e equivalente ao seu trabalho ou pagar-lhe mensalmente uma quantia arbitrada; ou sendo alugado à terceiro, recebendo o seu locatário os salários, ou finalmente lhe dando um prazo para lhe indenizar o que lhe restava.

Diz-nos ainda Narciso que com nada disso concordou seu locatário por lhe servir unicamente que ele continuasse a lhe prestar os serviços para descontar na razão de $5 \$ 000$ mensais "ou ser coagido a isso por meio de pressões repetidas e opressoramente". Termina a petição afirmando "que um tal contrato de locação de serviços é nulo pela proteção de todas as fórmulas exigidas por lei, é portando ilegal" e que é também injusto, porque, "ganhando mensalmente quantia superior a 30\$000, só lhe pagou seu locatário na razão de 5\$000”. (APEES, Inq. $\mathrm{n}^{\circ}$ 555, Cx. 673, 1879, fl. 2-3).

Pouco se legislou a respeito do trabalho livre no Brasil entre 1850, quando da extinção do tráfico de escravos, e 1888, com a abolição. De acordo com Maria Lúcia Lamounier, no que se refere ao trabalho livre e a contratos de locação de serviços, havia os títulos das Ordenações Philipinas, que tratavam dos contratos de serviços de criados, algumas disposições do Código Comercial relativas a serviços propriamente mercantis e, finalmente, as leis de 13 de setembro de 1830, e de 11 de outubro de 1837 . A lei de 13 de setembro de 1830 pode ser considerada a primeira medida concernente às relações de trabalho livre, nacional e estrangeiro no Brasil. Consta de apenas oito artigos que podem ser considerados simples e vagos. Já a lei de 11 de outubro de 1837 é um pouco mais complexa e compõe-se de dezessete artigos nos quais se dão providências sobre contratos de locação de serviços. Mas esta última lei se restringe a contratos estabelecidos com imigrantes. (Lamounier, 1988, p. 20).

Estas duas leis concernentes ao trabalho livre terão vigência por mais de quarenta anos até a entrada em vigor do Decreto $\mathrm{n}^{\circ} 2.827$ de 15 de março de 1879. Trata-se de um dispositivo legal menos genérico que as leis anteriores, com oitenta e seis artigos, nos quais se procura ordenar as obrigações de locatários e locadores, nacionais e estrangeiros. Mas este decreto de 15 de março de 1879, por sua vez, se limita a contratos de locação de serviços na agricultura. (Lamounier, 1988, p. 21). 
Como Narciso de Souza não era estrangeiro e não fora contratado para trabalhar na lavoura, em princípio, a lei que deveria reger suas relações de trabalho com Antônio Alves de Azevedo deveria ser a de 13 de setembro de 1830. Mas por se tratar de um liberto, e por ter justamente obtido sua liberdade com o aporte de recursos que lhe faltava para comprar sua alforria através de um empréstimo, com o compromisso de locar seus serviços, ou seu trabalho, àquele que lhe emprestou a quantia de que tinha necessidade, as relações contratuais entre Narciso de Souza e Antônio Alves de Azevedo passam a ser regidas por um dispositivo especial, a Lei de 28 de setembro de 1871, ou Lei do Ventre Livre. Esta lei previa, dentre outros dispositivos, que o liberto poderia contratar com terceiros a prestação de futuros serviços, por prazo que não excedesse sete anos, em favor de sua liberdade. Mas a Lei do Ventre Livre só dizia isso a respeito e não regulava as condições concretas em que estes serviços deveriam ser prestados, como também não o fazia a lei de 1830. Neste momento é que os problemas começam a aparecer.

A própria lei de locação de serviços de 15 de março de 1879 já indicava os problemas específicos quanto à locação de serviços de libertos recentes ao dispor que estes continuavam tendo seu trabalho regulamentado pela Lei do Ventre Livre, que os colocava durante cinco anos sob a inspeção do governo e com a obrigação de contratarem-se caso vivessem como vadios. $\mathrm{O}$ constrangimento ao trabalho cessaria com a exibição do contrato de serviço, que poderia ser efetivado até por sete anos. (Lamounier, 1988, p. 127-128).

A preocupação e a prevenção em relação à vadiagem à época, não só dos libertos, mas dos trabalhadores nacionais livres em geral, era grande entre aqueles que faziam, direta ou indiretamente, as leis. Em 1878, um ano, portanto, antes da lei de locação de serviços de 1879, realizou-se o Congresso Agrícola Rio de Janeiro. Peter L. Eisenberg, examinando as discussões e as proposições daquele congresso, nos dá uma ideia do que pensavam os fazendeiros participantes a respeito de como resolver o problema do que consideravam como falta de braços para a lavoura e, particularmente, a respeito do aproveitamento do trabalhador livre nacional. Começa por notar que curiosamente muitos dos participantes do congresso viam no trabalhador livre nacional uma fonte importante de mão de obra. Mesmo quando examina alguns depoimentos de fazendeiros desse grupo que classifica como de otimistas quanto às possibilidades de aproveitamento desses trabalhadores na lavoura, constata fortes visões preconcebidas: 
Os entusiastas do trabalhador livre nacional afirmaram que este vivia na ociosidade, estando desempregado ou subempregado, e por isso podia ser melhor aproveitado pela grande lavoura. Dos 'muito milhares de vagabundos e vadios', somente 'uma diminuta parte deles se aplica a algum serviço, trabalha um ou dois por semana, quando muito'. A comissão de lavradores de Baipendi condenou esta 'ociosidade, justamente estigmatizada pela moral como a mãe dos vícios, que por sua vez são as mães dos crimes, e que constituem um mal social que se ostenta sob proporções assustadoras no país'. (Eisenberg, 1989, p. 144)

Os fazendeiros participantes do congresso agrícola de 1878 concordavam a respeito da ociosidade do trabalhador livre nacional, mas discordavam quanto às causas e às curas desta ociosidade. As causas eram identificadas como falta de repressão, politicagem e ausência de incentivos positivos, sendo que "quem identificava a ociosidade como resultado da falta de repressão apelou para 'a correção e polícia que moralize e sujeite ao trabalho a classe jornaleira'. Muita gente pediu uma maior repressão da vagabundagem, 'uma boa lei de locação de serviços' e 'sumaríssimo processo"”. (Eisenberg, 1989, p. 145).

Já alguns representantes paulistas do Vale do Paraíba tendiam a culpar os próprios proprietários de terras pela ociosidade de seus trabalhadores, já que eram de opinião de que "os grandes proprietários abrigavam homens livres improdutivos em suas propriedades para fins eleitorais" (Eisenberg, 1989, p. 145). Maior senso prático revelou o representante do New London and Brazilian Bank Ltd. em Rio Claro, A. Scott Blacklaw, ao defender a imigração de cules $^{1}$ indianos. Segundo Blacklaw, 'a lavoura tropical, a lavoura de café, não serve para gente branca', porque 'não há branco que possa trabalhar pelo mesmo salário de um preto ou de um cule da Índia (muitos apoiados)'. Acrescentou ainda que os cules 'respeitam muito ao branco; não são barulhentos, são pouco dados à bebida, mesmo porque não ganham para alimentar este vício'. (Eisenberg, 1989, p. 154).

Visões como as expostas acima são marcadas pela ideia de que a escravidão em si teria deformado a tal ponto o escravo que, uma vez liberto, ele não teria condições de se inserir no mercado de trabalho ou em uma sociedade competitiva. Não há como negar a violência da escravidão, mas o reconhecimento desta violência não pode nos

Cules é a tradução do inglês coolie, que seriam colonos ou trabalhadores braçais oriundos da Ásia, normalmente indianos ou chineses, das colônias ou ex-colônias europeias. 
levar à coisificação do escravo e do liberto. Não podemos tomar a realidade da vida de cada escravo pelo seu estatuto jurídico. O escravo era considerado como um objeto de propriedade, mas isso não quer dizer que ele se visse como tal e nem mesmo que ele fosse sempre tratado como tal. Em relação aos libertos, as esperanças de liberdade e a luta cotidiana visando tal liberdade apenas reforçam nosso entendimento de que agiam como pessoas. A experiência mesma da escravidão também preparava para a liberdade, ou seja, "que as experiências de escravidão, deportação para o Novo Mundo e trabalho forçado fossem devastadoras não se pode negar. Mas que deixassem a maior parte dos escravos incapaz de recriar uma vida cultural é improvável". (Scott, 1991, p. 32).

Pela forma que foi redigida a petição do liberto Narciso de Souza, constando termos jurídicos e menção a leis e a decretos, fica claro que ela foi não só escrita como projetada ou idealizada por um advogado. Assim não podemos fazer um uso apressado desta petição para termos uma ideia mais clara do quanto Narciso estava consciente de seus direitos e deveres ou do quanto ele estaria preparado para trabalhar a partir de uma relação contratual, que no caso presente ainda era uma herança da escravidão, ou melhor, um preço que Narciso estava pagando para se livrar dela.

Não temos como dar uma resposta precisa do nível de conscientização deste liberto, mas talvez ela nem seja necessária, dados os elementos concretos do processo que estamos examinando, no qual a passagem à liberdade estava envolvendo uma avaliação do valor do serviço a ser prestado como equivalente de quantias a serem amortizadas. Examinando alforrias com remissão de serviços em Campinas a partir da década de 1860, alforrias que assumem feições muito próximas de um contrato de trabalho, Peter Eisenberg chama a atenção para o fato de que seus dados sugerem "que o próprio escravo, apesar de ter passado praticamente toda sua vida anterior como escravo, tinha condições de entender as equivalências entre dinheiro e tempo de trabalho, condições essas que podiam ter facilitado sua transição do regime de escravidão para o de trabalho livre". (Eisenberg, 1989, p. 292).

Temos ainda os fatos: Narciso já havia sido preso duas vezes por não se sujeitar aos termos do contrato firmado. Dispomos também do depoimento de quem lhe emprestou o dinheiro para sua liberdade, hipotecando seus serviços.

Em seu depoimento, o Sr. Antônio Alves de Azevedo confirma que contratou com o liberto Narciso de Souza os seus serviços por uma escritura pública que existe no cartório de Antônio Augusto Nogueira 
da Gama, mas que o tempo de prestação de serviços é de cinco anos e não sete anos como diz Narciso. Alega também que Narciso, "depois que contratou os seus serviços com ele respondente pouco tempo a isso se prestou, porquanto não somente nunca tratou de trabalhar, como até por sua má conduta e gênio nervoso, impedia que os escravos dele respondente cumprissem seus deveres". (APEES, Inq. n 555, Cx. 673, 1879, fl. 7).

Acrescenta ainda o Sr. Antônio Alves de Azevedo que:

já desesperançado de haver de Narciso o cumprimento do contrato que celebrara, viu-se na necessidade de requerer a prisão deste no intuito de ver se o corrigia e podia receber seus serviços em paga do dinheiro que lhe havia adiantado, mas que tudo fora improfícuo porquanto Narciso, saindo da prisão, tornou-se cada vez mais obstinado em não querer indenizá-lo. (APEES, Inq. $n^{\circ} 555$, Cx. 673, 1879, fl. 8).

Denise Aparecida S. de Moura, em seu trabalho ambientado em Campinas durante a segunda metade do século XIX, observa que, ao se discutir a prestação de serviços no Brasil do século XIX, pensava-se em meio a um contexto em que "interessava o prestar serviços, enquanto a prática, o dar ou fazer o trabalho, segundo as condições de um contrato". Assinala ainda que não faltavam observadores que acreditavam que na província paulista se dispunha de recursos domésticos que poderiam ajudar a colonização desde que colocasse em ação aqueles que 'fogem ao trabalho'. Esses mesmos observadores diziam ainda que a experiência lhes mostrava "que na última classe da sociedade brasileira, ou pelo menos na da nossa província [...] existia um grande número de cidadãos que "não prestava serviços correspondentes às suas forças"" (Moura, 1998, p. 77-78).

Esta fuga ao trabalho, que muitas das vezes era vista como uma mera falta de disposição para o trabalho, é tratada de uma forma muito original por esta historiadora nos seguintes termos:

Neste ponto ambíguo do discurso, encadeiam-se formas de conduta que viviam esse momento de maneira dissonante, porque a ideia de fuga não significa literalmente uma atitude de resistência ao trabalho, ou de ir embora, mas de estar prestando o serviço de uma dada maneira, ou de estar vivenciando o cotidiano do trabalho de um modo que para muitos não correspondia à capacidade de trabalho dessa gente da última classe. (Moura, 1998, p. 78). 
O Sr. Antônio Alves de Azevedo estava sentindo na pele que agora não era só ele quem dava as cartas e que nem a polícia estava conseguindo colocar seu trabalhador contratado nos eixos. Mais do que uma menor sede de ganhos com o trabalho alheio, o que faltava a ele, certamente, era uma melhor percepção do mundo do trabalho de sua época, mundo este que, aliás, não era exatamente novo, já que uma maioria de homens pobres livres já existia no Brasil desde o início do século XIX. Denise Moura nos dá uma boa descrição deste mundo de trabalho e de convivência:

Trilhando o cotidiano do trabalho é possível perceber a gente desse segmento, nas diversas conjunturas do declínio do escravismo, tratando-se para serviços diversos, sendo chamada por companheiros para dividir algum serviço contratado nas fazendas e sítios, combinando formas de contrato, negando prosseguir com uma obrigação que achava não ir bem, envolvendo-se em serviços de outros e negociando muito, até com aqueles que os ajustavam. $\mathrm{Na}$ multifacetação cotidiana, não eram os interesses dos proprietários que prevaleciam e conduziam um dado processo, uma vez que se convivia no sentido de uma intensa relação de tensões, interações e redefinições. (Moura, 1998, p. 118-119).

A partir da segunda metade dos anos 1970, houve uma grande renovação na produção historiográfica sobre a escravidão no Brasil, o que levou à formulação de novos problemas a respeito do pós-abolição. Como assinalam Ana Maria L. Rios e Hebe Maria Mattos, essas novas perspectivas levaram a uma abordagem das sociedades pós-emancipação mais centrada na experiência dos libertos, no estudo de suas aspirações e de suas atitudes em face do processo emancipacionista e dos novos contextos sociais por ele produzidos. Passou-se a dar ênfase à família do escravo, à sua vida cultural e comunitária, a considerar que ele negociava e às vezes atuava no mercado produzindo e vendendo bens e serviços por conta própria. Concluem as autoras que, "desta perspectiva, também as atitudes dos libertos passaram a ser analisadas como iniciativas que respondiam a projetos próprios, que necessariamente teriam interferido nos processos de reconfiguração de relações sociais e de poder que se seguiram à abolição do cativeiro" (Rios; Mattos, 2005, p. 26).

Voltando à petição de Narciso, verificamos que nela ele alega que ganhava mais de $30 \$ 000$ por mês e só recebia $5 \$ 000$ de seu locatário. Mas é somente em seu depoimento que ficamos sabendo como Narciso teve, por seus próprios meios, a consciência objetiva de sua exploração. Diz 
ele que "estava trabalhando nas obras de que é empresário Aleixo de tal, a quem fornecia cal que fabricava e de quem percebia a importância de seus serviços a qual era pelo mesmo Aleixo entregue ao dito Azevedo". (APEES, Inq. $n^{\circ}$ 555, Cx. 673, 1879, fl. 5).

Se analisarmos em conjunto o alegado na petição com os dois depoimentos, do locador e do locatário, as coisas ficam mais claras. Antônio Alves de Azevedo era um empregado público que, depois de hipotecar os serviços de Narciso, alugou ou sublocou, como queiramos, estes serviços a Aleixo de tal, que segundo Narciso era um construtor de casas em Vitória. Narciso veio a saber o quanto este construtor pagava a seu locatário Antônio Alves Azevedo. Foi assim que Narciso passou a se negar a trabalhar, e o que é mais grave, impedir, por meios que não conhecemos, que os escravos do Sr. Antônio Alves Azevedo trabalhassem.

Segundo João José Reis, em Salvador, durante o século XIX, a maioria dos africanos libertos fazia trabalho de escravos ao lado de escravos. Esses escravos entregavam uma parte do que ganhavam no dia para seus senhores da mesma forma que muitos libertos também o faziam para o pagamento de prestações, ou para cumprir cláusulas de cartas de alforria. Esta semelhança de situações o leva a concluir que "é como se na cidade o escravo embolsasse o que teoricamente era do senhor e o liberto desembolsasse em favor do ex-senhor o que teoricamente era seu". (Reis; Silva, 1989, p. 106).

Narciso se recusava a trabalhar, porque tomou consciência de que era explorado e talvez ele estivesse tentando mostrar a seus companheiros que eles também o eram. A tomada de consciência de sua exploração pode ser uma condição necessária, mas não é suficiente para deduzirmos que Narciso já tivesse o que poderíamos considerar como consciência de classe. Ainda não havia ali, no meio em que vivia Narciso, elementos objetivos para a constituição de uma consciência de classe, nos termos que normalmente se entende hoje, embora os estudos de Edward P. Thompson nos mostrem que esses homens do passado também não eram propriamente uns alienados.

Além de perceber concretamente que seu trabalho estava sendo remunerado abaixo de seu valor, o liberto Narciso de Souza já se sentia fazendo parte do mundo dos livres. Mais especificamente do mundo dos pobres livres, com quem já convivia há tempos, caso contrário não teria conseguido os recursos financeiros e culturais necessários para obter sua alforria. Neste mundo da pobreza livre, certamente Narciso se sentia melhor que na escravidão, porque nele havia modos de trabalhar e viver especiais: 
A arte de criar papéis informais de viver e trabalhar, inerentes ao processo histórico da pobreza livre, na segunda metade do XIX, enredava-se em manifestações ligadas ao lúdico, à musicalidade, ao desafio, à renovação dos laços de sociabilidade com os proprietários, parentes, vizinhos e outros indivíduos que cruzavam o seu cotidiano e o engenho de estar continuamente criando gestos, trejeitos, vozes e versos nas suas práticas de trabalho, informais ou não. Tais práticas compunham um gozar dotado de significados na vida dessa gente, que urdia, ao seu tempo e aos seus fazeres, ritmos arredios à lógica da acumulação. (Moura, 1998, p. 90).

Antônio Alves de Azevedo nos revela em seu depoimento que ele também tinha escravos alugados ao mesmo construtor Aleixo de tal, os quais trabalhavam junto a Narciso e que esta mistura estava se revelando perigosa. Provavelmente ele já começava a se arrepender do negócio que fez e a pensar que melhor seria ter comprado um novo escravo para alugar, ao invés de ter hipotecado os serviços de Narciso.

Mas o Sr. Antônio Alves Azevedo também tinha problemas com seus escravos. Em julho de 1873, um de seus escravos, Francisco, foi acusado de um roubo que houve em casa de um fazendeiro no distrito de Cariacica. Naquela ocasião, Antônio Alves de Azevedo teve que enviar seu escravo às pressas para o Rio de Janeiro para ser vendido. Não conseguiu, porém, evitar que seu escravo Francisco fosse preso na Corte e remetido à Vitória para ser processado. Não era um homem de muita sorte o Sr. Antônio Alves de Azevedo. (APEES, Inq. n ${ }^{\circ} 408$, Cx. 666, 1873, fl. 63-64).

Segundo Frederick Cooper, Thomas C. Holt e Rebecca Scott, com muita frequência os estudiosos da escravidão tratavam o período de trabalho livre que sucedeu a escravidão como um pano de fundo conceitual da servidão, indiferenciado e não investigado. Em suas críticas a essa forma equivocada de proceder, estes autores observam ainda que:

o trabalho escravo podia ser analisado em termos econômicos, sociais ou políticos, mas o trabalho livre costumava ser definido simplesmente como o fim da coação, não como estrutura de controle da mão de obra que precisasse ser analisada a seu próprio modo. Estas dificuldades conceituais e analíticas podem surgir, em parte, devido ao fato de que a noção de liberdade não está no passado nem em outro lugar; é o terreno histórico que habitamos hoje em dia, o sistema que governa nossa vida, nosso meio de vida e nossa consciência. (Cooper, et al, 2005, p. 42) 
O liberto Narciso se negava a cumprir uma relação contratual que, para ele, se revelava injusta. Provavelmente ele dissesse a si mesmo que como ele havia comprado sua liberdade, agora ele se recusava a trabalhar como um escravo.

Não é outra coisa, ou seja, trabalhar "como o fazia quando escravo", que previa uma escritura de locação de serviços que fez o liberto Nicolau a Manoel Ferreira da Silva em junho de 1885, a qual, apesar de um pouco extensa, transcrevemos abaixo por causa de sua importância como documento histórico:

Traslado da escritura de locação de serviços que faz o liberto Nicolau a Manoel Ferreira da Silva

Saibam quantos este público instrumento de escritura ou locação de serviços verem, que no ano do Nascimento de Nosso Senhor Jesus Cristo de 1885, aos 13 dias do mês de junho, nesta cidade da Victoria e em meu cartório compareceram, como outorgante o liberto Nicolau, escravo que foi de Antônio de Alvarenga Rangel, e como outorgado Manoel Ferreira da Silva, moradores nesta mesma cidade, reconhecido pelos próprios de que faço menção, e me apresentaram a distribuição que se segue: [...] a escritura de locação de serviços que faz o liberto Nicolau com Manoel Ferreira da Silva por espaço de quatorze meses, para pagamento da quantia de cento e cinquenta mil réis que emprestou ao mesmo liberto Nicolau. Victoria, 11 de junho de 1885.

O Distribuidor - Fernandes Magalhães - dizendo-me o mesmo liberto Nicolau em presença de duas testemunhas abaixo nomeadas e assinadas, que tendo tomado por empréstimo a quantia de cento e cinquenta mil réis $=150 \$ 000$, ao outorgado Ferreira da Silva para complemento do valor, pelo qual se libertara, contratou locarlhe, como efetivamente loca, por meio da presente escritura, seus serviços por tempo de quatorze meses a contar de hoje; e se sujeita a trabalhar-lhe, como o fazia quando escravo, dentro daquele prazo para pagamento da referida quantia de cento e cinquenta mil réis; devendo, porém, o outorgado locatário dar a ele outorgante locador cama e mesa, roupa para o trabalho, e curá-lo nas enfermidades ligeiras e de curta duração; pois que naquelas que excederem de oito dias a despesa correrá por conta dele locador, que para fiel comprimento do quanto aqui estipulado fica, se sujeita às disposições legais que regem a matéria. Pelo outorgado Ferreira da Silva foi dito que aceita esta escritura de contrato a ele feita e conforma-se com as condições nela contidas. Pagou o mesmo locatário a quantia de setecentos e cinquenta réis do imposto provincial [...].

(Assinado a rogo do locador por não saber ler e escrever). (APEES, Inq. $n^{\circ}$ 976, Cx. $n^{\circ}$ 693, 1886, fl. 3). 
Pela escritura podemos ver que além de constar que o liberto Nicolau se sujeitaria a trabalhar para o outorgado como o fazia quando escravo, constava também que o locatário dos serviços de Nicolau se responsabilizava pelo seu tratamento apenas no caso de doenças de curta duração, entendidas como tais aquelas que não excedessem a oito dias.

O problema é que Nicolau adoeceu por um mês, e as despesas com seu tratamento se elevaram a $46 \$ 720$ (quarenta e seis mil e setecentos e vinte réis). Assim, em 19 de agosto de 1886, o locatário dos serviços de Nicolau, Manoel Ferreira Dias, cidadão brasileiro naturalizado, padeiro, estabelecido em Vitória, apresentou queixa em juízo contra o locador Nicolau, porque este se recusava naquele momento a prestar-lhe os serviços correspondentes a um mês como indenização do tempo em que esteve doente e mais os serviços correspondentes ao valor de seu tratamento, chegando ao ponto de abandonar sua casa e ir servir na Padaria Nacional, onde, naquele momento, se achava. (APEES, Inq. $n^{\circ} 976$, Cx. $n^{\circ} 693,1886$, fl. 2).

Novamente um liberto que se recusava a trabalhar como trabalhava como quando era escravo. E neste último caso a condição era explícita na própria escritura de locação. Esses senhores que emprestaram seu dinheiro a Narciso e a Nicolau deveriam estar decepcionados. Assim não haveria como modernizar as relações de trabalho no país em se tratando desses ex-escravos que se consideravam "donos de seu nariz".

O trabalho nunca deve ser considerado de forma isolada, e sim inserido num sistema de relações sociais, ou ainda:

Em qualquer contexto histórico, é provável que os escravos e outros trabalhadores subordinados sejam mais que instrumentos passivos da vontade de outrem. Mas a partir de meados do século XIX as relações de trabalho mudaram fundamentalmente. $\mathrm{O}$ trabalhador livre era agora uma possibilidade imaginável, com frequência labutando na cidade ou numa fazenda próxima, e chegava a ser norma em muitos lugares. Em consequência, a aparente contradição de escravidão e trabalho semilivre numa era de liberdade era mais que um problema abstrato. Os próprios trabalhadores, muito provavelmente, teriam consciência da ambivalência política que cercava sua situação e podiam muito bem agir para forçar a solução do problema. Além disso, a luta para tornar-se um trabalhador livre poderia evoluir rapidamente rumo à luta para tornar-se um cidadão livre. (Cooper, et al, 2005, p. 73). 
Na província do Espírito Santo, os escravos davam grande importância à compra de sua liberdade. Entre 1873 e 1883, esta província ocupou o terceiro lugar no Brasil quanto à utilização de fundos dos próprios escravos para obterem sua alforria, superada apenas pelas províncias do Rio Grande do Sul e de Minas Gerais. Ainda nesse mesmo período a província do Espírito Santo ocupou o quarto lugar na utilização do Fundo de Emancipação para alforriar escravos. (Gebara, 1986, p. 71).

Leila Algranti afirma, a nosso ver sem maiores fundamentos, que a maior parte dos libertos não conseguia se integrar na sociedade; muitos se transformando em mendigos e prostitutas. Afirma ainda que "a dificuldade de se integrarem na sociedade tornava-os muitas vezes vítimas de sua condição" (Algranti, 1988, p. 123). A autora parece não levar em consideração um dado fundamental, que é o de que muitos escravos se libertavam com suas próprias economias ou com suas economias e um aporte adicional, o que revela que já tinham alguma integração na sociedade e, especificamente, uma integração em termos de trabalho; além do mais, se o seu destino era a miséria na maior parte dos casos, como se explica o grande desejo dos escravos de se libertarem? Seria por teimosia? Certamente que não.

Os libertos procuravam fazer com que suas vontades prevalecessem mesmo em relação ao que havia sido pactuado e expresso em um contrato. Assim, nem sempre valia o escrito. A liberdade conquistada era reafirmada pelas demandas de ajustes em relação ao que fora objeto de contratos formalizados. O escrito possuía seus limites. A afirmação de liberdade se sobrepunha aos contratos. Ser "dono de seu nariz" era muito importante.

\section{Referências}

ALGRANTI, Leila M. O feitor ausente: estudo sobre a escravidão urbana no Rio de Janeiro. Petrópolis: Vozes, 1988. 223 p.

ANDREWS, George R. Black and white workers: São Paulo, Brazil, 1888-1928. Pittsburgh: Hispanic American Historical Review, n. 68: 3, p. 491-524, 1988.

CHALHOUB, Sidney. Visões da liberdade: uma história das últimas décadas da escravidão na Corte. São Paulo: Companhia das Letras, 1990. 287 p.

COOPER, Frederick et al. Além da escravidão: investigações sobre raça, trabalho e cidadania em sociedades pós-emancipação. Tradução de Maria Beatriz de Medina. Rio de Janeiro: Civilização Brasileira, 2005. 346 p.

BURGUIÈRE, André. Histoire d'une histoire: la naissance des Annales. Paris: Annales: E. S. C., n. 6, p. 1347-1359, 1979. 
EISENBERG, Peter L. Homens esquecidos: escravos e trabalhadores livres no Brasil, séculos XVIII e XIX. Campinas, SP: Ed. da Unicamp, 1989. 396 p.

FARGE, Arlette. Dire et mal dire: l'opinion publique au XVIII' ${ }^{\mathrm{e}}$ siècle. Paris: Seuil, 1992. 317 p.

FERNANDES, Florestan. Imigração e relações sociais. Rio de Janeiro: Revista Civilização Brasileira, ano 1, n 8, 1966, p. 75-95.

. A integração do negro na sociedade de classes: o legado da "raça branca". 3. ed. São Paulo: Ática, 1980. 2 v. 814 p.

GEBARA, Ademir. O mercado de trabalho livre no Brasil (1871-1888). São Paulo: Brasiliense, 1986. 222 p.

LAMOUNIER, Maria Lúcia. Da escravidão ao trabalho livre: a lei de locação de serviços de 1879. Campinas, SP: Papirus, 1988. 176 p.

MATTOS, Hebe Maria. Das Cores do Silêncio: os significados da liberdade no sudeste escravista - Brasil, século XIX. Rio de Janeiro: Nova Fronteira, 1998. 379 p.

MOURA, Denise Aparecida S. de. Saindo das sombras: homens livres no declínio do escravismo. Campinas, SP: Área de Publicações CMU/Unicamp, 1998. 314 p.

REIS, João José; SILVA, Eduardo. Negociação e conflito: a resistência negra no Brasil escravista. São Paulo: Companhia das Letras, 1989. 151 p.

RIOS, Ana Maria L.; MATTOS, Hebe Maria. Memórias do Cativeiro: família, trabalho e cidadania no pós-abolição. Rio de Janeiro: Civilização Brasileira, 2005. 301 p.

SCOTT, Rebecca J. Emancipação escrava em Cuba: a transição para o trabalho livre, 1860-1899. Tradução de Maria Lúcia Lamounier. Rio de Janeiro: Paz e Terra; Campinas, SP: Ed. da Unicamp, 1991. 309 p.

\section{Fontes:}

APEES (Arquivo Público do Estado do Espírito Santo), Inquérito n 408, Caixa 666, 01.07.1873, Summario de Culpa de Francisco, escravo de João Rodrigues de Souza, réo preso, denunciado pelo Promotor Público, 70 fls. manuscritas.

APEES, Inquérito $n^{\circ} 555$, Caixa 673, 07.08.1879, Traslado dos autos de habeas corpus, Narciso de Sousa, Paciente, 11 fls. manuscritas.

APEES, Inquérito $n^{\circ}$ 976, Caixa ${ }^{\circ}$ 693, 19.08.1886, (Sem título), 4 folhas manuscritas. 